\title{
Perspective ideologice şi viaţă culturală în "Ateneu” (ianuarie-iunie 1966)
}

\author{
Conf. univ. dr. Oana CENAC \\ Centrul interdisciplinar de studii culturale central și sud-est europene, \\ Universitatea „Dunărea de Jos” din Galați
}

\begin{abstract}
The purpose of our study is to present the main articles published in "Ateneu" (between January and June 1966) in order to describe the ideological frame for the literary production of the epoch.
\end{abstract}

Keywords: "Ateneu”, ideology, culture, literature.

Revistă de cultură, editată de Comitetul regional pentru cultură și artă Bacău, „Ateneu" publică, pe parcursul anului 1966, o serie de articole care oferă cititorului o amplă perspectivă asupra vieţii literare şi culturale româneşti din perioada respectivă. În continuare, vom prezenta principalele articole publicate în intervalul ianuarie-iunie din anul respectiv, ordonate în funcție de rubricile care le cuprind.

Vlad Sorianu semnează cronica dramatică la două piese de teatru: Simple coincidențe de Paul Everac și Sfântul Mitică Blajinul de A. Baranga. Simple coincidențe este o piesă care "pune încă o dată chestiunea contradicțiilor dintre vârste, problemele specific diferitelor generații", toate acestea aflându-și în piesa lui Paul Everac „un numitor comun în imperativul recunoașterii necesității de a evolua, de a crește, ridicat la rangul de criteriu moral". Remarcând jocul actorilor și afirmânduși preferința pentru anumite personaje, cronicarul e de părere că "regia ar fi putut adăuga un plus de omogenitate ritmului, dacă ar fi suprimat momentul, fără însemnătate scenică, al intermezzo-ului din partea întâi (eventual, să fi găsit o altă soluție, deoarece aceasta e prea convențională) și dacă ar fi renunțat complet la episodul discuției dintre moș Florică și Daniela, care nu-și are altă justificare, decât de a anunța moartea profesorului Coman și întâlnirea cu Sorin. Asemenea literaturizări, ca în aceste două fragmente, găsim și în alte locuri, ceea ce rărește textura dramatică a lucrării altfel, după cum s-a văzut, bine gândită scenic."

În cea de-a două piesă recenzată - Sfântul Mitică Blajinul - cronicarul e de părere că „satirizarea e paroxistică, frizând un grotesc de natură să acuze fără cruțare". Sub raport tematic, se consideră că „e vorba de variații cromatice pe aceeași temă: a potlogăriei șmechere, care mimează tot mai dificil corectitudinea, a servilismului carierist, care e luat tot mai rar drept atașament." În ceea ce privește regia piesei, 
realizată de "debutantul Gh. Miletineanu”, cronicarul apreciază că aceasta „s- $a$ menținut în datele textului", acesta fiind motivul, crede cronicarul, pentru care "unele personaje nu și-au găsit relief scenic."

În rubrica "Cronica literară”, Constantin Călin prezintă două volume: „Viaţa deocamdată” de Ion Alexandru şi „Continentele ascunse” de Grigore Hagiu. Despre „Viaţa deocamdată” se afirmă că: „Oroarea de locuri comune mi se pare a fi trăsătura izbitoare a acestei frumoase cărți de versuri, spiritualiceşte juvenilă, însă cu mari semne de talent în cuprinsul ei. (...) El vine cu un fond pimar de perceptii, de extracție rustic, fascinant prin vigoare; vine cu un apetit grozav al concretului, cu toate canalele senzoriale deschise, şi - ceea ce-i mai important - cu aptitudinea de a-şi organiza impresiile într-o matrice, altfel spus, vine cu o viziune personală."

Viaţa deocamdată are semnificația „unui îndemn și, în același timp, a unei negații. Cartea impune un barem valoric ridicat, autorilor și criticilor. (...) În planul estetic, Ion Alexandru este (...) «un presupus răzvrătit». În final, recenzentul este de părere că evoluția ulterioară a scriitorului se va înscrie "dinspre romantismul tulbure și expresionism înspre solemnitatea clasică."

Volumul lui Grigore Hagiu trebuie citit cu „răbdarea unui radiolog, datorită proteismului sub care se ascunde eul poetului." Lirica sa se remarcă "atât prin acuitatea și mobilitatea notațiilor, dar mai ales prin finalitatea explorărilor." Sub aspect tematic, "cartea configurează un program etic generos, care vizează "geneza interioară» a omului contemporan." Lirica sa este o "lirică de idei, $\hat{\imath}$ accepțiunea notorie a expresiei. Remarcabilă se pare aptitudinea sa de a plasticiza stări morale, (...) de a discerne în ordinea afectivă perisabilul de rezistent, de a inregistra cu sensibilitate mutațiile ideilor. (...) Poetul face dovada unei sensibilități elevate, se exprimă însă prudent; o infuzie de vitalitate ar da "Continetelor ascunse» așteptata consistență și un relief impresionant."

În articolul „Între istorie și critică literară”, Ion Apetroaie semnalează apariția unui studiu de sinteză istorico-literară, semnat de profesorul D. Micu, al cărui obiectiv central a fost de a surprinde „ecranul primelor două decenii literare ale veacului nostru. (...) D. Micu întreprinde un examen sistematic asupra curentelor, a publicațiilor și a poeziei (vol. I) urmate de unul asupra celorlalte genuri (vol. II) din literatura primelor două decenii ale veacului nostru." Ultimul tom cuprinde etapa literară (1900-1918) și „suscită interesul prin abundența și adâncimea problemelor, prin strădania scriitorilor de a reflecta mai viu aspirația spre un stil nou." Recenzentul consideră că „preocuparea istorico-literară a autorului s-ar fi cerut mai viu simțită în fixarea seriilor istorice de scriitori, în raportările acestora la anumite curente ori sublinierea direcțiilor stilistice mai importante." Cercetarea este organizată în „sinteze în bună măsură personale, de un real folos pentru tinerii cititori cărora se 
adresează în primul rând." Considerând lucrarea drept „un bun îndreptar în studiul unei etape literare", Ion Apetroaie apreciază volumul ca fiind "structurat cu grija informării exacte, a comentariului consistent și totodată limpede, cu atenție față de treptele valorice ale operelor considerate." Micile erori semnalate nu sunt decât "insule cu totul singuratice pe întinderea unei sinteze nu numai de pionierat, dar și de calitate."

În articolul „Calistrat Hogaș - primul director al gimnaziului din Piatra Neamț", I. Nacu evocă perioada în care autorul a fost „profesor și director la gimnaziile din Piatra Neamț, Tecuci, Iași, Roman etc." unde "și-a adus, încă din tinerețe, contribuția la procesul de luminare a nenumăratelor serii de elevi. (...) Cu toate greutățile și mijloacele materiale extreme de reduse, gimnaziul din Piatra condus în faza sa de început de tânărul scriitor moldovean, a constituit un mare pas înainte în opera de luminare a poporului. Impetuoasa dezvoltare a actualului liceu «Petru Rareș» din Piatra Neamț își are originea în modestul gimnaziu condus de Calistrat Hogaș."

I. Sîrbu, în articolul „Lucian Blaga - memorialist”, prezintă volumul de amintiri Hronicul și cântecul vârstelor (Editura Tineretului, București, 1965), în care are loc "consemnarea și, în același timp, interpretarea lirică a unor evenimente de epocă, raportate la vârstele interioare ale poetului."

Structural, volumul este „prin excelență poematic: un mare liric își analizează retrospective anii de formație, cu intenția implicită de a-și explica sieși și altora drumul de mai târziu al operei. (...) Ca orice mărturie confesivă, întreprinsă în lumina unei sincerități absolute, Hronicul contribuie la întregirea profilului lui L. Blaga cu trăsături mai puțin cunoscute, sau altele care abia ar fi putut fi bănuite. (...) Arcuit pe spațiul primelor 24 de vârste din viața poetului (1895-1919), acest edificiu biografic, pe care Blaga îl așează asemenea unui memento la intrarea monumentalei sale opere, impune prin varietatea arhitectonicii, la care își dau concursul materiale din cele mai diferite, toate trecute prin filtrele unei remarcabile sensibilități lirice."

Apreciindu-i valoarea literară, I. Sîrbu consideră că, deși „divers în privința procedeelor compoziționale, Hronicul aduce o multitudine de situații și evenimente din care se încheagă trepat și unitar profilul unui scriitor și al unei vremi."

$\mathrm{Cu}$ „Evocare: Ștefan Petică”, Nae Antonescu „reconsideră opera poetică a lui Ștefan Petică” care a rămas „o problemă nerezolvată a cercetătorilor de istorie literară. (...) Poezia lui Petică este o incantație lirică, mai mult sugestivă decât aplicată spre valorile picturale descriptive, de largi acorduri muzicale." Alături de creația lirică „compunerile în proză sunt o altă față poetică a autorului” și reprezintă „scurte notații lirice, fără viziune epică obiectivă, mai mult amintiri și evocări ale unui trecut, de multe ori îndurerat." 
În calitate de „doctrinar și ideolog artistic", Ștefan Petică „dovedește o bogăție de informație, pe mai multe planuri." În această calitate, Petică „elogiază activitatea lui Maiorescu de harnic plivitor de buruieni din grădina literaturii române", iar interesul său vizează în special ",apărarea poeziei simboliste de multiplele atacuri." Fără a considera definitivă demonstrația sa, Nae Antonescu concluzionează: „iată numai câteva idei și fapte în care a crezut cu pasiune Ștefan Petică. Acestea și altele vor trebui studiate cu atenție pentru a contura fizionomia unui poet nedreptățit de soartă."

În „Fișă de istorie culturală”, D. Vatamaniuc publică articolul "«Telegraful român» din Sibiu și moldovenii", în care, sprijinindu-se pe o bibliografie de specialitate, menționată la final, realizează un istoric al acestui ziar punctând rolul important pe care acesta l-a avut în contextul istoric al vremii: „Menirea ziarului era - se arată în Prenumerațiune - să «pună poporul român în relațiune cu lumea și cu tot ce se întâmplă într-însa, spre a i se înălța și lui spiritul și spre a i se deștepta puterile sufletești și trupești ca să știe ce și cum trebuie să lucreze pentru cultura și fericirea sa.»"

În articolul „Pentru o monografie Artur Gorovei”, Al. Bardieru surprinde personalitatea celui care "după sporadice încercări - mai întâi cu caracter liric, apoi epic - pe la diferite publicații ale vremii, se va regăsi in studiile de etnografie și folclor." Amintind activitatea desfășurată în paginile revistei de folclor "Șezătoarea", Al. Bardieru enumeră și exemplifică cu titluri reprezentative domeniile de interes ale lui Artur Gorovei. Astfel, sunt amintite: domeniul folclorului și al studiilor de folclor, domeniul studiilor de istorie literară și culturală, lucrările de popularizare în domeniul folclorului și scrierile literare. În finalul articolului sunt amintite jurnalul zilnic pe care l-a ținut cu consecvență scriitorul și corespondența vastă ,,adunată și păstrată cu grijă în câteva zeci de mape masive", care „studiate, ar constitui un foarte prețios izvor pentru istora noastră literară."

Vlad Sorianu semnează cronica literară „Două romane - două etape ale epicii noastre actuale: Francisca de Nicolae Breban și Moartea în pădure de Constantin Țoiu". Demersul recenzentului nu se dorește unul comparativ între cele două cărți "(...) fie și pentru că abordează periode ale formării conștiințelor și orânduirii noi, diferite. Ca să nu mai amintesc de concepțiile cu totul distanțate ale celor doi autori asupra rigorilor romanești." Astfel, la Nicolae Breban recenzentul identifică „o filogenie prestigioasă, cu rădăcini în romanul psihologic dintre cele două războaie mondiale; unele câș̦tiguri de tehnică din proza faulkneriană aduc acea notă de tablou sinoptic al mișcărilor de conștiință." Pentru Vlad Sorianu, „Francisca” este 
un roman care "vine într-un moment de relativă penurie a reușitelor exemplare în domeniul romanului", este "un fel de bilanţ al experiențelor de până atunci."

Pe de altă parte, romanul lui Constantin Țoiu aparține „unei perioade anterioare, de cristalizare a prozei contemporane". În romanul său, Țoiu folosește "conflictul central - angajat între forțele pozitive și cele ale reacțiunii - drept punct de plecare pentru incursiuni ample în trecutul unor personaje." În ceea ce privește formula romanului la care apelează scriitorul, Vlad Sorianu e de părere că avem de-a face $\mathrm{cu}$ "un mod conștiincios de a povesti cât mai mult despre cât mai multe. Adică, materialul de viață nu e explorat intensiv, vertical, ci extensiv."

În recenzia cărții Tendințe actuale în proza noastră științifico-fantastică, semnată de Voicu Bugariu, se fac comentarii pe marginea locului nedrept pe care-l ocupă acest tip de literatură în ierahia literaturii române, fapt determinat de „apariția nemeritată a unor producții facile, șablonarde, străine de rice tangență cu arta autentică." Dezvoltareea științei și tehnicii în civilizația secolului nostru nu putea să nu se reflecte în literatură având ca efect dezvoltarea literaturii de tip science-fiction atât pe plan internațional, cât și național: "Scriitori ca Mihu Dragomir, Adrian Rogoz, Ion Hobana, Sergiu Fărcăşanu, Vladimir Călin, Camil Baciu, Radu Nor, Gh. Săsărman, G. Anania, R. Bărbulescu sunt autorii unor povestiri sau romane științifico-fantastice remarcabile prin efortul și reușita lor de a sluji dezideratele majore ale literaturii noastre actuale."

Se identifică două tendințe majore care se manifestă în literatura română de tip science-fiction: „prima este ilustrată de proze scurte, intens lirice, emoționante variațiuni anticipative pe teme etern umane. (...) A doua tendință cuprinde povestiri și romane ce aduc în dezbatere, pe căile alegorice specifice genului, aspecte esențiale ale evoluției umanității privite printr-o prismă filozofică."

Concluzia recenzentului este că „succesele prozei noastre științificofantastice sunt numeroase (...) Povestirile și romanele științifico-fantastice apar în tiraje mari și sunt citite cu predilecție de adolescenți și tineri ce au gustul artistic în formare", iar acest aspect "trebuie avut în vedere de autorii unor astfel de lucrări."

În rubrica „Bibliografie”, George Pătrar prezintă volumul lui Vasile Rebreanu, Călăul cel bun, "o suită de alegorii în care mijloacele literare recunoscute sunt abandonate dintr-un spirit ostentativ de înnoire a expresiei. Vasile Rebreanu pornește de la concepte morale (inocența, cinismul, iubirea, fericirea etc.), personificându-le".

Lucrarea cuprinde „elemente și procedee ale basmului popular, divagații metaforice și simboluri care amintesc de primele poeme în proză ale autorului. (...) «Romanul» este susținut de talentul incontestabil al autorului, însă nu creația primează aici, ci experimentul. Dialogurile copiază ceea ce-i exterior (maniera) în dialogurile 
personajelor lui Eugen Ionescu, și nu au darul să intereseze. (...) Desele aluzii la evenimente istorice și literare dau cărții un caracter abstract. (...) În ansamblu, romanul dă impresia de ceva fabricat în laborator, artificial." Pornind de la opinia lui G. Călinescu despre esența procesului de creație (enunțată în „Conicile optimistului", (E.P.L., 1964, p. 320): „Creația este o clarificare a unei ordini întrevăzute în natură (...) ceea ce te izbește într-o adevărată operă de artă este claritatea ei globală unită însă cu impresia spontaneității."), George Pătrar punctează astfel tot ceea ce îi lipsește romanului lui Vasile Rebreanu.

În articolul „Însemnări ieșene”, Ilie Dan prezintă istoricul revistei cu același titlu care a apărut la Iași, după mutarea „Vieții românești” la București, în 1933. Demersul intelectualilor, grupați în asociația ieșeană „Pietenii Universității”, viza „înființarea unei mari reviste literare și științifice în genul acelora cu care Iașul a putut să se mândrească până mai ieri, o revistă care să cuprindă toată mișcarea intelectuală a țării și pe cea străină." Programul a fost redactat de Mihail Sadoveanu, iar principalele linii directoare ale acestuia erau: „punerea în valoare a specificului nostru în cultură; unificarea sufletească a neamului; sporirea valorii umane in toate direcțiile; educarea tineretului; spiritualizare fără dogmatism." Literatura pe care o promovează revista "are un caracter umanist și militant, e legată de năzuințele celor mulți și obidiți, având rădăcini trainice în realitățile românești." Domeniile variate abordate în paginile revistei „au solicitat colaborarea majorității intelectualilor ieșeni" alături de poeți și prozatori. Având o existență scurtă (apariția revistei a fost suspendată în același timp cu cea a „Vieții românești”, în 1940), "Însemnări ieșene” a avut „un profil democratic, formulând revendicări în numele celor mulți, a promovat arta realistă, specificul național și limba populară în literatură." Revista s-a remarcat printr-o „atitudine hotărâtă contra fascizării țării și contra curentelor decandente, iar prin ceea ce are valoros a contribuit la dezvoltarea presei progresiste interbelice".

În „Glose critice”, Vasile Sprici comentează pe marginea „revirimentului pe care l-a cunoscut proza noastră în decursul anului trecut". Autorul remarcă „o tot mai accentuată «desepicizare», prin renunțarea treptată la anecdoticul baroc, la discursivitate și explicativ” și „o diversitate apreciabilă a modurilor de exprimare, a stilurilor, o efervescență înnoitoare". Este remarcat interesul tinerilor pentru „preluări din nume ilustre: $e$ de dorit, firește, ca tinerii noștri prozatori să cunoască și să valorifice, în spațiul spiritual al literelor românești, și superioara virtuozitate lingvistică a autorului lui «Ulysses», și analitismul asociativ al creatorului lui Swan și subtilitatea problematic nediscursivă a Nathaliei Sarrante și densitatea intelectuală, fecundată de umanism a lui Camus, Ionescu etc.. Dar în același timp avem obligația (...) de a evidenția în faptele de artă propriul nostru aport, individual și național la făurirea 
valorilor autentice". Se au în vedere "producțiile literare în genul scurt" care "se înscriu sub aceeași frământată zodie a căutărilor". Debutanții dovedesc "mai mult discernământ”, iar responsabilitatea lor în fața cititorului anunță „nu numai talente, ci și conștiințe civice lucide." Sunt amintite prozele care cultivă „modalități diverse, dar întâlnindu-se pe un ridicat plan valoric." Alături de aceștia, Vasile Sporici îi menționează pe cei care formează o „pletoră de reformatori și inovatori ad-hoc, pentru care lumina tiparului a răsărit prematur." Finalul articolului învită la reflecție: „Nu se pot da nici un fel de rețete, dar se poate reaminti tinerilor prozatori care-și caută profilul, că acesta este o chestiune de talent, de cunoaștere a vieții, a poporului, de cultură complexă și nu una de mimetism cu orice preț."

C. D. Papastate semnează articolul „Vasile Alecsnadri și «Jurnalul său intim»" în care se fac o serie de observații privind această lucrare mai puțin cunoscută de publicul larg. Tipărit în 1947, manuscrisul jurnalului fusese scris cu o sută de ani înainte când, "în plin elan al tinereții, poetul cunoștea una dintre cele mai mari iubiri pe care le-a încercat în decursul vieții sale." Intervalul temporal pe care-1 cuprinde jurnalul este "7/19 iunie 1846", data plecării lui Alecsandri din Iași, și „se sfârșește la 4 mai 1847, data morții Elenei Negri.” Jurnalul cuprinde „impresii, frământări sufletești, uneori dramatice (...), pagini cu adevărat umor pe care poetul știe să-l plaseze cu bun simț, justețea observației satisfăcând spiritul, iar poanta neașteptată creând o atmosferă de destindere." Finalul articolului afirmă, oarecum premonitoriu, observația că " "Jurnalul» cuprinde în germene elementele care vor impodobi mai târziu, creația literară a poetului."

Al. Săndulescu semnează articolul „Duiliu Zanfirescu - contribuții biografice” din rubrica „Portrete de familie”, în care, plecând de la documnetele vremii, surprinde istorul descendeței cunoscutului scriitor. Demersul autorului pare justificat mai ales că „după deconcertatul discurs de recepție la Academie, rostit in 1909, originea socială a lui D. Zanfirescu a constituit obiect de atac și controversă." Consultând arhivele și familia, se reconstituie "arborele genalogic a trei generații de ascendenți ai scriitorului, încercând astfel să clarificăm controversele nu o dată oțioase". Rezultatul acestei analize evidențiază faptul că „Diuliu Zanfirescu provenea dintro familie cu o statornică tradiție de cultură din partea tatei și cu remarcabile predispoziții artistice din partea mamei. (...) Nepot al doctorului Anastase Lascăr și al lui Ghoerghe Zamfir, doctor în filozofie, nepot al pictorului Ștefan Mincu, D. Zamfirescu s-a născut într-o familie pentru care cel mai de seamă preț a fost pus cu consecvență pe bunurile culturii și frumusețile artei. Acesta este adevăratul act de noblețe al originii sale."

În rubrica „Opinii”, C. Isac semnează articolul „Criterii ale comediei” în care pledează pentru o comedie satirică care „descinde din sarcasmul mucalit al lui 
Păcală și din satira virulentă a lui Caragiale." Acest tip de comedie se distinge "printr-o atitudine clară, bine înscrisă $\hat{n}$ istoria vremii, dând conținut concret obiectului derâderii și estimând o atitudine civică." Personajele luate în vizor, reflectă "diferit, dar palpabil, o lume de dincolo de baricada pe care s-a postat autorul. Aceste personaje existau virtual, se înscriau în realitate și poziția activă față de ele avea rezonanțe imediate. (...)Preluând de la înaintași causticitatea ironiei și forța demascării totale, autorii de comedie au dat la iveală o bogăţie de stiluri, de mijloace, de deosebiri în gradul satirei, care au lărgit considerabil acest tradițional sector de teatru românesc." Analiza lui C. Isac are în vedere câteva nume din epocă: Tudor Mazilu, Sergiu Fărcășanu, Al. Mirodan, Aurel Baranga, Radu Cosașu, Ion Băieștu, Aurel Storin, Paul Everac, pentru ca în final să concluzioneze: „comedia satirică românească actuală nu-și are încă contribuția pe care o merită la veselia activă din sălile de spectacol. Pe sub zidurile teatrelor se mai strecoară multe lucrări mediocre acceptate din lipsă de altceva, iar critica se grăbește uneori să acorde titluri de garanție unor comedii care înseamnă încă prea puțin."

În articolul "Garabet Ibrăileanu-«critic complet»", Ion Apetroaie creionează personalitatea cunoscutului critic care „inclinat spre știință, format la școala pozitivismului francez, din fericire, senzitiv și om de gust sigur, avea să statueze pentru critică principii științifice". Citând articolul "Greutățile criticii estetice" („Viața românească”, nr. 1, 1928, p. 144), Ion Apetroaie evidențiază concepția critică a lui G. Ibrăileanu: „Critica literară, așa cum s-a constituit de ani încoace, este un tot. Critica estetică, critica psihologic $\breve{a}$, critica științifică sunt părțile acestui tot. Critica literară, când privește opera din toate punctele de vedere este completă."

În prima fază a criticii sale, Ibrăileanu era de părere că „însăși selecția pentru analiză a unei opere presupune prin aceasta și o judecată de valoare. In anii criticii complete, contaminat atât cât trebuia de compania estetică, el ținea să noteze explicit necesitatea criticii estetice ca fiind primordială $\hat{\imath}$ actul critic. (...) Critica literară, susține Ibrăileanu, ca și arta de altfel, are și un rol cultural (...) este un auxiliar în instruirea cititorului." Sugestia, subiectivitatea și tehnicismul sunt „serios amendate de Ibrăileanu, în numele esteticii realiste, care impune confruntarea operei cu viața. In această confruntare (...), critica estetică, singură, nu face decât să impuțineze viața dintr-o operă, de vreme ce accentul critic cade numai pe aproximație și pe tehnicism."

Concluzia lui Ion Apetroaie este că „G.Ibrăileanu sintetizează istoria criticii noastre de la critica militantă, a determinismului social, de tipul Gherea, până la critica noastră de azi, integrală, complexă, convocând principii științifice ca obiectivitatea, explicarea cauzală, dialectică, fără a omite însă judecata de valoare, implicită ori pronunțată." 
N.Gr.Stețcu semnează articolul „La «România viitoare»” în care prezintă activitatea de publicist a lui Garabet Ibrăileanu, o latură mai puțin cunoscută de publicul cititor: activitatea desfășurată la periodicul socialist „România viitoare” din Brăila. În prima parte a articolului, semnatarul încearcă, relatând diverse știri, să contureze mai pregnant profilul acestei foi care apare din martie 1888 până la 23 mai 1890, având ca redactor responsabil pe Th. Mănescu. Menționând câteva articole a căror paternitate aparține lui G. Ibrăileanu, Stețcu presupune că "activitatea de publicist la acest periodic trebuie să fi fost destul de susținută, în sensul că va fi colaborat aici până către 23 mai 1890, când aceasta încetează să mai apară." Autorul include în articolul său două Anexe: prima dintre ele cuprinde studiul lui Ibrăileanu „Dragostea ca mijloc de perfecționare a specie omenești”, iar cea de-a doua anexă cuprinde o carte poștală aparținând lui Cezar Vraja.

În articolul „Un mare îndrăgostit de viață”, Radu Negru face o serie de observații pe marginea eseului „Meditații în fața morții”, care completează opera critică, literară și didactică a lui Garabet Ibrăileanu pe care „îl dezvăluie ca pe un profund gânditor. (...) Concepția științifică despre lume, profundul realism al scriitorului fac parte din structura unică a spiritualității lui. Portretul moral cunoscut al lui Garabet Ibrăileanu îl simțim împlinit cu ultimele «meditații în fața morții», prilej pentru un adevărat elogiu adus muncii, valorilor și frumuseților ei, moment de afirmare în plină lumină a unui îndrăgostit de viaţă."

La rubrica „Cronica literară”, Vlad Sorianu semnează articolul „Pasiunea certitudinilor simple - pe marginea volumelor de versuri «Lacrima diavolului» de Ion Bănuță și «Fântâni și stele» de Ion Brad”. Salutați de G. Călinescu, Al. Philippide și Perpessicius, cei doi poeți reprezintă „două lire menite a stărui cu timbrul lor distinctiv" care s-au remarcat ,într-o perioadă când lirica noastră trecea prin prefaceri mari și când pe firmamentul poeziei se arătau și atâtea stele căzătoare." Realizând o radiografie critică a volumului lui Ion Bănuță, Vlad Sorianu remarcă „ponderea copleșitoare a pieselor de fermă orientare, în care identificăm patriotism, atitudine antirăzboinică și antifascistă și alte linii de forță ale unei conștiințe de poetas vates." Este un volum care vine cu o „detașare programatică față de tirania modei. Poate se simte și o ostentație anti-inovatoare cu unele lunecări în comodități, dar sigur că se simte artă autentică."

Despre Fântâni și stele, Vlad Sorianu e de părere că „lirismul lui Brad a evoluat pe linia eliminării exteriorizărilor zgomotoase sau interiorizărilor expediate. Luciditatea devorantă a autorului ascunde intenții polemice, la adresa prejudecății că ar exista participare emoțională și fără o limpezime care să antreneze înțelesurile."

Ca o concluzie a celor două analize critice, Vlad Sorianu consideră că volumele „reprezintă o nouă expresie a diversității de stiluri (...), ele exprimă realitatea 
că diversitatea nu înseamnă numai prosperitatea experimentalismului, ci coexistența deopotrivă a literaturii care, în primul rând, își propune să îmbogățească tradiția lirică și să înmulțească modalitățile comunicabilului său."

În articolul „Două eseuri valoroase”, V. Sporici semnalează apariția în „Luceafărul” din 19 și din 26 februarie a eseului „Problema «înstrăinării» în filozofia și estetica marxistă” de Gheorghe Achiței și a articolului „Adevăr și verosimil” de Gheorghe Stoica. Cele două esesuri "atrag atenția prin actualitatea temelor abordate, prin stringența și profunzimea argumentației, precum și prin eleganța cu care discută opiniile diferite sau adverse." În eseul amintit, Gh. Achiței tratează „problema alienării, arătând că este vorba despre unul dintre conceptele centrale ale filozofiei contemporane" care ocupă un loc central în viziunea existențialiștilor. Pe de altă parte, în articolul său, Gh. Stoica analizează „variatele aspecte ale adevărului artistic”, respingând „exagerăruile nihiliste cu privire la realizările artistice naționale ale perioadei anterioare."

Andrei Sebastian semnalează în „Pilula record” apariția celei mai scurte „schițe" scrise vreodată în literatura română. Este vorba despre lucrarea lui Vasile Baran, intitulată „Dirijorul”, o lucrare de șapte rânduri, a cărei lectură durează treizeci de secunde. Autorul lucrării este un "partizan focos al prozei "pilulă», încărcată de simboluri și de voioase subtilități."

În „Condiția științifică a criticii”, Vasile Sporici susține că „dezideratul major al criticii noastre actuale este cel al diversificării." Se pledează pentru o critică care să aibă „aceleași ambiții novatoare ca și poezia sau proza tânără. (...) Intrebarea ce stimulează asemenea preocupri este: în ce măsură critica ține pasul cu beletristica, dacă nu cumva - în cazul când metodologia critică rămâne unificată sub raportul căilor și tehnicii de investigare, al cerințelor și obiectivelor ei analitice - criticii s-ar putea trezi în rolul unor nivelatori, ai aducătorilor la un numitor comun." Pentru stabilirea unei viziuni dialectice, istoriste asupra fenomenelor artistice, V. Sporici constată că în critica literară actuală se aplică cu consecvență o serie de conceptă filozofice. Unul dintre acestea este cel de „alienare” sau înstrăinare elaborat de Hegel, reluat de Marx și întâlnit în întreaga filozofie existențialistă. „Critica curentă de la noi utilizează acest concept mai mult în înțeles negativ, ca produs al proprietății private și generator al înstrăinării omului de esența sa." În "Manuscrisele” lui Marx din 1844, conceptul de alienare are un dublu sens: cel menționat mai sus și cel de obiectivare „,̂n măsură să asigure autocunoașterea." Un alt concept este neliniștea care „este legată de latura pozitivă a procesului de înstrăinare, ea însoțind avatarurile regăsirii omului în actul artistic."

În finalul articolului, Vasile Sporici găsește utilă „preocuparea criticii pentru psihologie. Numele lui Freud sau C.W.Jung pot fi citate într-un context estetic 
ce-și propune să cuprindă tendința de dezînstrăinare a omului pe calea explorării acelor zone atât de omenești ale difuzului psihic, al subconștientului. Este vizibil că o critică modernă fără solidul temei al filozofiei, cu domeniile sale subordonate sau adiacente, cum ar fi estetica, psihologia etc., nu poate fi concepută."

În „Perspective actuale în cercetarea literară”, Al. Săndulescu realizează o trecere în revistă a ceea ce a presupus „acțiunea de valorificare a moștenirii literare" care a înregistrat "succese remarcabile, mai întâi, prin ediții din operele clasicilor tipărite în tiraje de masă și apoi prin interpretările noi, în spiritul filozofiei materialist-dialectice." $\mathrm{Nu}$ sunt pierdute din vedere "studiile judicioase de sinteză despre anumite epoci literare, monografii bine documentate despre autori de seamă și primul volum din tratatul academic de "Istoria literaturii române»". Desigur că au existat și "fenomene de superficialitate, de ingustime de vederi și vulgarizare a unor teze teoretice, ceea ce a determinat scăderea nivelului teoretic al cercetărilor." Toate aceste aspecte sunt astăzi "depășite, iar cercetarea în domeniul istoriografiei literare iș̦i afirmă consecvent caracterul științific." Sunt menționate studiile recente despre opera lui M.Eminescu, I.Creangă, I.Slavici, A.Macedonski, T.Arghezi, L.Blaga, paginile special consacrate de reviste lui V.Alecsandri, N.Iorga, M.Sadoveanu, L.Rebreanu, O.Goga, G.Ibrăileanu, G.Călinescu. "Încep să fie studiați cum se cuvinte mari critici și oameni de cultură ca Titu Maiorescu, Eugen Lovinescu sau scriitori de seamă ca Duiliu Zanfirescu, Ion Barbu, Ion Pillat, Vasile Voiculescu, Ionel Teodoreanu ș.a. (...) Cele mai izbutite studii de sinteză și monografii aduc puncte de vedere noi, abordează unghiuri inedite, polemizează argumentat cu istoria literară mai veche, denotă suplețe ideologică și finețea gustului estetic."

În ceea ce privește planurile de viitor, Al. Săndulescu fixează câteva obiective: „Prima sarcină de însemnătate națională(...)este aceea privind intensificarea muncii de elaborare a "Tratatului de istoria literaturii române», din care s-a publicat până acum numai volumul întâi.(...)Paralel cu elaborarea tratatului, se pregătesc ediții critice, monografii despre scriitori și grupări literare, studii de sinteză, colecții de corespondență și documente inedite. O și mai mare atenție va trebui acordată acelor scriitori interpretați o vreme în mod eronat (Titu Maiorescu, N. Iorga, L. Blaga), genurilor și curentelor literare. Se susține necesitatea apariției unor studii despre „istoria romanului românesc, despre romantism, realism, modernism. (...) Se simte tot mai acută necesitatea generalizărilor, a unor lucrări de revalorificare a teoriei literare. (...)Aici ar putea fi înglobată și o istorie a criticii și esteticii literare românești, privind exoluția conceptelor celor mai importante."

Concluziile autorului sunt optimiste căci „preluând tradițiile naționale și umaniste ale unor iluștri înaintași ca N.Iorga, G.Călinescu, T.Vianu ș.a., istoriografia 
literară românească actuală, îmbogățită cu experiențele trecutului și dispunând de metoda de cercetare dialectică, are un drum larg deschis înainte."

Constantin Călin semnează cronica literară cu titlul „D. Micu - N. Manolescu: literatura română de azi” în care analizează studiul „Literatura română de azi, sinteză istorico-literară de neîndoielnică utilitate - un tablou al operelor și promoțiilor de autori activi în ultimele două decenii - realizată prin colaborarea criticilor D. Micu și N. Manolescu". Lectura primului volum relevă „Cutezanța celor doi critici de a supune unui sistem un material nestratificat de timp, adesea proteic, îndeletnicire nu fără de riscuri, însă într-o fază incipientă, nu și fără de satisfactii."

Meritul volumului semnat de cei doi autori este acela de "a contura o priveliște verosimilă a reliefului literar curent, de care orice clasificație ulterioară va trebui să țină, în bună parte, seama". Analizele care compun cartea sunt expuse „într-un stil elevat, reușind nu numai să informeze cititorul, dar și să-i procure anumite satisfacții artistice (...). Dacă stilistic cei doi autori nu se armonizează, ei par să comunice perfect la nivelul principiilor și al atitudinilor față de obiectul studiului." Lucrarea este tributară contextului ideologic în care apare căci „cei doi critici își legitimează observațiile sintetizând din documentele istorice și de partid idea că «literatura însuflețită de idelurile epocii socialiste nu este o literatură informă, la discreția reproducerii nesemnificative sau a exercițiilor fără sens.» Raportată la lucrările anterioare, ineditul „Literaturii române de azi” constă în „clasificația valorilor și, mai puțin, în interpretarea lor. În genere, imaginea scriitorilor și operelor este surprinsă cu acuitate, în ceea ce au particular, unic."

Sunt prezente și note critice: „După opinia noastră, nu este îngăduit ca atunci când consacri un articol elogios romanului Setea de Titus Popovici, să abandonezi într-o notă subsolică romanul Mitrea Cocor de Mihail Sadoveanu. Destul de sumare și de incomplete sunt analizele dedicate lui Camil Petrescu și George Călinescu, în raport cu cea dedicată lui Zaharia Stancu. Duscutând despre Desculț, ar fi fost vrednică de amintit filiația, evidentă în planul stilistic și chiar sub raportul situațiilor, cu povestirea Cordun de Eusebiu Camilar, apărută exact cu un deceniu mai înainte. (...) O inadvertență ne apare neprevederea, în secțiunea despre nuvelă, a unui scriitor format, George Bălăiță, primit la apariția volumului Călătoria (1964), cu satisfacția de critică."

În final, cronicarul constată că dincolo de „observațiile de ordin științific ori metodologic, (...) cercetarea criticilor D. Micu - N. Manolescu nu și-a propus să fie exhaustivă, perfectă și am exagera examind-o în funcție de un tip ideal de sinteză istorico-literară, cum, la fel, am exagera tratând-o cu ostentivă îngăduință. Prezența ei era mai mult decât necesară: obligatorie!" 
În articolul „Sentimentul responsabilității”, Constantin Cubleșan identifică „un sentiment al marilor responsabilități umane, al certitudinii de a fi stăpâni pe soarta, pe destinele și idealurilor proprii, comune omenirii revoluționare" care "domină, sau mai precis, definește, creația celor mai tinere generații de poeți, crescuți și afirmați în ultimele două decenii."

Autorul identifică „idea comunității poetului cu însăși patria-mamă, cu destinele ei ce sunt conduse cu mână sigură de partidul clasei muncitoare. Țelurile, idealurile de viață sunt comune și este firesc deci ca exprimarea personalității, definirea umană însăși a poetului tânăr să se facă prin condiția apartenenței sale la acest partid." Este menționat Nicolae Stoian cu poemul „Fișă personală”, Radu Cârneci cu „Poem”, Ion Crînguleanu cu poezia „Confirmați-mă”, Doina Sălăjan cu "Omului". În toate aceste poezii, se simte "nevoia exprimării entuziaste a unui mesaj optimist, (...) privirile rămânând neclintit ațintite spre partidul care veghează și le conduce destinul. Prinos de recunoștință acestuia va aduce fiecare poet, închinându-și viața și opera întreagă cauzei partidului. (...) Opera însăși este rodul, ea constituie împlinirea datorată însușirilor înaltelor idei revoluționare ale acestuia (...) Spre soarele central al ideilor revoluționare exprimate cu luciditate de partid, se concentrează intreaga forță creatoare a țării." Reprezentative sunt considerate a fi versurile poemului, „Partidul”, semnat de Nicolae Labiș, „cel mai reprezentativ poet al generației tinere."

I. Sârbu semnalează apariția monografiei Gheorghe Şincai de Mircea Tomus,, o lucrare care „se înscrie ca o primă încercare izbutită de amplă valorificare, în lumina contemporaneității socialiste. (...) Munca autorului se concentrează, în special, spre conturarea unui portret interior, sprijinit pe datele obiective ale cercetării, in afara interpretărilor tendențioase și a legendei bogat țesute în jurul istoricului ardelean. Călăuzit de principiile materialismului dialectic și istoric, monografistul subliniază semnificația diverselor etape din biografia lui Șincai, prin referiri permanente la fondul social-politic al vremii în care marele luminator și-a desfășurat activitatea."

În rubrica „Bibliografie”, Dumitru Nica recenzează volumul lui G.I.Tohăneanu - Studii de stilistică eminesciană, o lucrare care completează seria de studii stilistice consacrate unor scriitori (Ion Creangă și Tudor Arghezi) reprezentativi ai literaturii noastre clasice și contemporane. Analizând prima secțiune a cărții, dedicată limbii și stilului poeziilor de tinerețe ale lui M.Eminescu, recenzentul consideră că "tratatrea mai largă, dezvoltarea unor capitole, în special al celui de sintaxă poetică, ar fi sporit valoarea și așa sigură a acestei prime părți. S-ar fi putut studia procedeele sintactice pentru realizarea contrastului și antitezei, întâlnite frecvent în poezia de început, de romantism dezlănțiut a tânărului Eminescu, și care dau o culoare dramatică acestei perioade." Partea a doua a cărții 
evidențiază „,cu deplină vigoare, pregătirea de filolog complet și finețea de estetician a autorului. (...) Bogăția de fapte adunate și riguros ordonate și tratate (...) la care se adaugă claritatea și acuratețea expunerii fac din ea un instrument foarte util de lucru."

Petre Pallu semnează articolul „Dimitrie Gusti - inițiator și organizator al Muzeului Satului” în care sunt elogiate eforturile depuse de „cercetătorul neobosit al satului, animatorul vieții culturale în mediul rural" pentru clădirea acestui muzeu care "să imagineze un sat românesc."

I.D. Lăudat semnează articolul „Ibrăileanu și cursurile sale universitare”, o analiză retrospectivă a acestor prelegeri care, însumate în diferite ediții, reprezintă aproximativ două mii de pagini. Cunoscutul critic literar împarte istoria literaturii române moderne în patru epoci literare, în funcție de anumite evenimente social-politice: "Motivarea împărțirii în cele patru epoci se găsește expusă in partea introductivă la fiecare epocă literară din cursurile sale, în "Introducerea" la "Opera literară a d-lui Vlahuță" (Iași, 1912), în articolele de sinteză publicate în "Viața românească", "Însemnări literare", în volume ca "După război" (Iași, 1921), "Cultură și literatură" (București, 1933), în cursul de "Estetică literară" ținut în anul 19251926. Concepția expusă cu aceste ocazii are rădăcini în epoca sa socialistă (1889-1895) și este afirmată consecvent de-a lungul întregii sale activități de istoric literar. (...) Trecând la studiul literaturii române moderne dintre 1800 și 1916, Ibrăileanu distinge (...) patru epoci, denumite după scriitorii reprezentativi, însumând în ele literatura specifică etapelor istorice de care se leagă. Prima epocă a literaturii române moderne Epoca lui Conachi - «coincide cu sfârșitul istoriei noastre vechi, cu ultimele zile ale vechiului regim».(...)Acestei epoci $\hat{\imath} i$ urmează epoca scriitorilor care reprezintă «literatura de luptă, literatura propagandistică»."

A doua epocă - Epoca lui Alecsandri - cuprinde două faze care corespund unor evenimente social-politice ce au influențat literatura respectivă. Prima fază a fost influențată de revoluția lui Tudor Vladimirescu care afirmă „idea de eliberare socială și de independență națională”. A doua fază a acestei epoci este numită „literatura cu adevărat nouă” și cuprinde opera care „însumează năzuințele sociale și naționale ale tinerei burghezii românești, aliată cu masele populare in lupta cu vechea orânduire."

În jurul anului 1880 se configurează Epoca lui Eminescu - „epoca cea mai strălucită a literaturii noastre." Alături de acești autori a căror operă literară a fost cercetată ",în amănunțime”, există și perioade din literatura noastră care nu au fost acoperite în detaliu, ca de exemplu „epoca care a avut ca punct de plecare anul 1900, ai cărei scriitori reprezentativi erau Sadoveanu și Goga". Fenomenul literar de după 1916 „era analizat în seminarii, pe care singur le conducea, pe bază de referate alcătuite de studenții anilor mai mari." Pentru Garabet Ibrăileanu "fenomenul artistic 
trebuie judecat în strânsă legătură cu viața, cu societatea", concluzionează semnatarul articolului.

„Un articol, inedit de Pompiliu Constantinescu” semnează L.Voița la împlinirea a două decenii de la moartea profesorului. Pretextul articolului îl constituie apariția în epocă a unui volum de note de călătorie care a fost, între altele, subiectul dialogului dintre autorul articolului și profesorul Pompiliu Constantinescu: "- Să știi, domnule Voița, că totuși nici românul nu-i tembel în străinătate. Este uluitor cu cât spirit critic știe să privească și cu câtă condescendență, dar și cu mândrie de sine, de nația lui, aprobă sau dezprobă ceea ce vede dincolo de granițe. Și totuşi avem o destul de redusă literatură a însemnărilor de călătorie. Poate și fiindcă devenim sentimentali de îndată ce trecem granița sau ne lăsăm uneori prea copleșiți de noutate... Ei, dar iată cum din vorbă în vorbă, pornind de la o carte proastă, $\hat{i} t ̦ i$ vin și idei bune. Ce interesante ar fi (...) niște causeries gen Sainte Beuve despre călătorii români în străinătate, văzuți după ani de la moartea lor."

Ideea profesorului Constantinescu s-a materializat în articolul „Călători români în străinătate: Dinicu Golescu”, semnat de același L. Voița: „Excepțional «băgător de seamă», boierul nostru ne-a transmis primul contact cu civilizația apuseană exact acum 116 ani; și mirându-ne așa cum s-a mirat, cu ochii mari deschiși, a trezit mirarea unui neam întreg, deschizându-i ochii spre Occident, de unde am primit lumina și de unde și-a aflat demnitatea lui de om, de latin și de român. Golescu-acest pionier al civilizației apusene în ținuturile noastre îmbâcsite de orientalism - i se cuvin astăzi toate elogiile între care efigia de "primul român modern», strălucește ca o emblemă pe fruntea lui semeață, pe care a înălțat-o din zarea noastră închisă, spre cerul luminos și înalt al Occidentului."

În rubrica "Consemnări”, Radu Cârneci semnalează apariția volumului „Intoarcerea din Cythera”, semnat de Veronica Porumbacu. În viziunea recenzentului, "trecerea timpului, implacabila trecere, cred că constituie - alături de poezia dragostei așezate, mature, și de peisajul marin și vegetal - principala coordonată a culegerii de poeme riguros selecționate. Trăirea retrospectivă, sondarea unoir stări în aparență de liniște și trecută durere, reflecții acoperite de emoții autentice se întâlnesc în această carte de împlinire a virtuților poetice ale Veronicăi Porumbacu, cu o anumită legănare de vis, cu o ceață transparent - albastră de ore care se duc." Parafrazându-1 pe G.Călinescu, semnatarul articolului concluzionează că „după lectura acestor poeme te cuprinde visul și timpul, persistent, ca o apă de cer, care nu se mai termină."

Al doilea articol din rubrica "Consemnări” este semnat de Ovidiu Genaru și are în vedere volumul Poezii de Romulus Vulpescu: „Volumul lui Vulpescu este un act unic în fenomenul poetic actual. El cultivă poezia și cartea trebuie judecată ceea ce este, nu ceea ce se aștepta ea să fie.(...)Vulpescu laudă poezia ca 
înnobilare a sufletului, e calm, scrie parcă la lumânare, scrie pe albume, pe papirusuri, pe ediții rare. Este puțin floretist, spumos, causeur.(...)Sunt cărți ce se citesc dimineața, altele seara (...) Am în față o carte ce se citește în liniște, necesară, lipsită de șabloane, necesară și încântătoare. Îl felicit pentru marea grijă manifestată în prezentarea grafică rafinată și de bun gust. Este o carte «a la Vulpescu» și e bine așa."

Rubrica „Cronica literară" gazduiește, sub semnătura lui Vlad Sorianu, prezentarea volumului de versuri Miracole, semnat de Petre Stoica care "ni se infățișează ca artist de elevată condiție intelectuală, ceea ce nu trebuie neglijat când te aproprii de recentul său volum" care se remarcă prin "simplitatea uneori îngrijorătoare a versului, austeritatea imagistică, atonalismul prozodiei, lipsa ostentaţiei intelectuale, o anumită dezarmare în fața sincerității eruptive a cotidianului." Toate aceste atribute sunt "produse ale unui temperament artistic cenzurat de setea autenticității, de teama convenționalului și a pozei." În aceeași măsură, sunt semnalate și aspectele "obositoare": „uniformitatea procedeelor care îmbracă, unele, schema: enunțarea laconică a motivului, colajul de elemente figurativ-descriptive, vizarea unor efecte plastice și, în concluzie, acea atmosferă nostalgică, de un vag nu atât misterios, cât nedecantat. (...) o poezie de asemenea soliditate civică, în care percepția realității se însuflețește de dragoste delicată față de oameni, nu poate să nu depășească unele steze lirice și să nu dobândească atributul plenarității."

A doua lucrare prezentată este volumul de debut Secvențe dintr-o margine de lume, semnat de Corneliu Buzinschi: "Cartea de debut este remarcabilă mai ales în măsura în care valorifică magma tematică a realităților noastre și nu numai, iar în al doilea rând din punctul de vedere al unor tehnici literare, supuse ca tot ce-i modern...demodării.” Se remarcă „prospețimea incontestabilă a eroilor, curățenia aspirațiilor unei lumi pe care desprinderea dintr-o existență larvară o aduce la nivelul demnității umane."

În finalul articolului, Vlad Sorianu subliniază că „prozatorul nostru lasă frânturile sale de amintiri, crâmpeiele de dialog, tipurile de o diversitate caleidoscopică să se constituie în structuri emoționale aparent spontane (...). La aceasta se adaugă o organică aderență la actualitate, cât și la tradiția literară, uneori cu ecouri folclorice (mai puțin evidente în cartea de față), ceea ce furnizează garanția unei conștiințe scriitoricești susținută de promițător talent."

Fr. Munteanu-Rîmnic semnează articolul „Copilăria și tinerețea lui Nicolae Iorga" în care elogiază „una dintre cele mai covârșitoare personalități, care a dominat viața științifică și literară a țării sale, de-a lungul unei jumătăți de veac." Autorul articolului realizează o succintă prezentare a originilor viitorului savant, a greutăților pe care le-a avut de înfruntat, mai ales în perioada copilăriei când, la vârsta de cinci ani, rămâne orfan de tată. Toate acestea nu l-au 
impiedicat să-și făurească o cultură solidă, „să-și închine întreaga viață luptei pentru afirmarea ființei naționale, în cadrul culturii umanității - luptă ajutată de o minte fără seamăn, de un efort titanic și o bravură civică ce-l așează în Panteonul Patriei!"

Cu prilejul împlinirii a cincizeci de ani de la nașterea Magdei Isanos, în articolul „Prezența poetei”, Gheorghe Drăgan elogiază personalitatea poetei, în versurile căreia "se face simțit dramatismul necontenitei lupte interioare dintre suferință și dragostea de viață. Eroul liric se detașează de aspectele statice ale existenței, risipindu-se în natură prin multitudinea senzațiilor, spre a se recompune (...) sub imperiul legii unității vieții."

Articolul „Vârsta poetului”, semnat de Platon Pardău, problematizează pe marginea "Poeziei tinere": "Calificativul a devenit blazon pentru o seamă de poeți și e abordat cu o ostentașie deloc lăăudabilă. Mai mult, direct sau nu, în unele cazuri între poezia tânără și poezia de valoare se pun automat semnele egalității. Se adaugă apoi premiile Uniunii Scriitorilor, conferite tinerilor,(...)articolele-bilanț despre tinerețea poeziei, poezia tânără, entuziasmul poetic etc., unde sunt citate mereu aceleși câteva nume, și iată-ne în fața unui fals tablou al poeziei noastre contemporane din care lipsesc autorii prestigioși." Platon Pardău dezaprobă poziția unor critici literari care „exclud din discuțiile literare sau tratează superficial creația unora dintre valoroșii noștri poeți.(...)Asemenea omiteri sau tratări expediate ale unor poeți talentați, reprezentativi, se întâlnesc destul de frecvent în paginile revistelor literare."

Creionând contextual epocii, autorul ajunge la concluzia că „(...) disocierile amenință să devină manie în critica noastră literară. Nu ne referim la disocieri de idei sau de fenomene, ci avem în vedere un sistem la fel de superficial de a aborda creația literară: împărțirea poeziei pe regiuni, zone geografice etc. Firește, fiecare scriitor aduce cu el ceva din aerul de unde se trage, însă a considera că harul poetic autentic îi garantează mai sigur ambianța bucureșteană, e cel puțin trist pentru autorii unor asemenea opinii".

În finalul articolului, autorul pledează pentru responsabilitate în actul critic, „pentru mai puține râuri inutile de cerneală și pentru dezbateri mai atente, profunde, împotriva acestor înregimentări biologice și geografice care, devenite argument critic hotărâtor, vădesc (...) resursele precare ale unor condeie de a înțelege matur fenomenul literar contemporan, atât de multiplu divers; dar, în același timp, rezultând într-o unicăși tânără vârstă care e însăși poezia noastră actuală."

În cadrul rubricii „Aniversări - George Călinescu”, Marcel Duță semnează articolul „Anticipări pseudonime ale «Cronicii mizantropului»" în care creionează „cariera publicistică prodigioasă, de o nedezmințită integritate interioară și într-o expresie mereu elevată, rar întâlnită atunci într-o literatură aflată la 
confluența raționalismului francez cu spiritul balcanic.(...)Colaborarea lui G.Călinescu la «Adevărul literar și artistic»(...)este de-a dreptul surprinzătoare pentru cine-și limitează cercetarea la colecția revistei: ea începe cu nr. din 10 ianuarie 1932 printr-un fragment din «Viața lui Eminescu» (...), prin scurte recenzii, note în pagina de «Cărți și Reviste», pentru ca chiar de la al cincilea număr al colaborării sale, din 7 februarie, să preia «Cronica literară» pe care o va scrie cu regularitate până la apariția «Jurnalului literar» (1939).(...)Din seria cronicilor sportive inserate în paginile «Adevărului literar și artistic» e sigur că «Natațiune, box, motociclism», «BOX», din 29 mai și «Inot» din 5 iunie - semnate Sportiv și, probabil, a cincea - Inotul din 24 iulie - nesemnată, aparțin lui G. Călinescu."

În cronicile sale sportive, Călinescu relevă, ca și Camil Petrescu, „o viziune a sporturilor în aspectul lor estetic și psihologic." Preocupat de dezvoltarea armonioasă integrală a individului, de înnobilarea lui cu un sentiment de existență colectivă, Călinescu împarte sporturile în două clase: „,in falsele sporturi de natură spectaculoasă, în care satisfacția este de natură nervoasă și în sporturile propriu-zise care dau o tensiune mai mare a vieții corporale".

Cele cinci cronici de modă - „O mare aliată ancestrală, Stimulentul vitrinelor, S-o luăm de la epidermă, Cosițele femeii, Ochii și sprâncenele semnate Dandy, „sunt impregnate de istorismul călinescian caracteristic, de numeroase asociații livrești(...)de aceeași idee persistentă a reluării în variantă modernă a antichității.(...)Cronica turistică (...)devine în expresie călinesciană cronica balneară, semnată Ovidius. Paternitatea celor patru exemplare - Tekirghiol, Tekirghiol - Movilă, Tekirghiol - Eforie, Pe plajă - este neîndoielnică.(...)prin conținut și prin structură, cronicile balneare sunt adevărate cronici ale mizantropului, cu interesul dominat de a face observațiuni în privința locurilor și moravurilor cuprinzând totdeauna sensuri de critică socială.(...)Regăsim(...)același spirit preocupat de înțelegere a psihologiei oamenilor, de clasificarea lor tipologică, de decantarea sensurilor generale, estetice în întâmplările cele mai obișnuite, de încadrarea vieții contemporane într-un cadru istoric larg de cultură universală, care era propriu artistului G. Călinescu."

În articolul „Despre Torquato Tasso”, Mihaela Șchiopu analizează studiul lui G. Călinescu prin care încearcă să-l plaseze pe poetul italian „într-o justă echivalență a valorilor". Relevând particularitățile studiului lui Călinescu, autoarea remarcă: "În primul rând te izbește personalitatea criticului care trece prin observația și analiza proprie orice afirmație. Sunt prezente gusturile, simpatiile personale, o atitudine proprie ce conferă studiului său o culoare aparte. Nu citim un studiu despre Torquato Tasso, ci îl ascultăm pe Călinescu vorbindu-ne despre Tasso, așa cum l-a înțeles și cum l-a apropiat el. (...) Farmecul deosebit al studiului îl formează însă 
meditația personală continuă a autorului. Analiza literară îi oferă mereu prilejul unor observații de ordin etic sau estetic."

Ca o concluzie, autoarea articolului punctează liniile de forță ale studiului lui Călinescu: „Amestec de părere proprie și analiză documentată obiectivă, de amănunt și asociație largă, de narație și metaforă, studiul critic al lui Călinescu ne oferă o interpretare originală și profundă a lui Tasso. Fiindcă la el nu vom întâlni niciodată locuri comune, superficialitate sau delăsare, ci pasiune și efervescență, integrare elegantă și profundă în ființa și opera poetului pe care îl analizează."

Vlad Sorianu semnează cronica literară la volumul „«Jurnal» de Eugen Barbu”. Se evidențiază existența a două genuri de memorialistică: „unul se întemeiază pe relatarea conștiincioasă a întâmplărilor cotidiene, pe înfățișarea filmului vieții, la care autobiograful face comentarii ad-hoc, reflectând optica lui de atunci(...). Un al gen memorialistic prin excelență este cel al amintirilor, al confesiunilor, al reconstituirii trecutului din perspectiva unei vârste venerabile, a sedimentării și decantării îndelungi, de unde nostalgie, dar și detașare, poezie, dar și adevăr." Jurnalul lui Eugen Barbu se revendică din ambele genuri căci „multe sunt pasajele datate anterior anilor noștri, în care se recunoaște clar optica prezentă, dacă nu chiar etapa actuală a meșteșugului.(...)Tot un argument în sprijinul afirmației că avem de-a face cu ceva intermediar între amintiri și însemnări zilnice, mi se par relatările cu privire la cristalizarea conștiinței ideologice a viitorului ofițer.(...)Ceea ce este surprinzător și confirmă o dată în plus că Barbu e prozator de talent în primul rând, pamfletar în al doilea, și eseist numai din când în când, e faptul evident că atunci când transcrie pagini literare relativ finisate sau proiecte de romane, autorul a la el acasă, senzația de poză, penibilitatea sunt cu totul excluse, te cucerește prin autenticitatea neștirbită."

În rubrica "Glose critice (III)", Vasile Sporici semnează articolul "Condiția filozofică a criticii” în care aduce în discuție una dintre dezbaterile literare ale vremii: „Definirea criticii ca sinteză a judecății valorice cu comparația între intenția artistică și rezultatul obținut, cu situarea istorică a operei și diagnosticul său ideologic (...) A exclude știința, ca și etica de altfel, din sfera criticii înseamnă a accepta implicit teza fundamentală a «Criticii puterii de judecată» cu privire la autonomia esteticului. Dar în timp ce Kant admitea necesitatea unui ideal moral pentru artă, adepții «criticii contemplative» limitează critica la postura de justificatoare (SaintBeuve), sau de «culegătoare», «lămuritoare» (Lovinescu), exclud datoria ei de a proclama idealuri în artă. Cred că în subsidiarul unora din atitudinile exclusiviste ale interlocutorilor actualei dezbateri este conținută și această omisiune, sau măcar riscul ei, adică al unei critici a-morale." Plecând de la observația lui Adrian Marino din articolul „Obiect și metodă”, Vasile Sporici subliniază ideea că „reconstituirea critică presupune analiză și sinteză în aceeași măsură. Aș completa introducând în 
discuție categoriile de logic și istoric. E nevoie de ele în măsura în care romanul, de pildă, își propune să surprindă caracterele și realitățile in spe, intr-o perspectivă dinamică, deci istorică."

La rubrica "Cărți. Reviste”, G.Pătrar semnează articolul „Gabriel Dimisianu: Schițe de critică" în care recenzează primul volum al lui G. Dimisianu, volum care cuprinde cronici, articole, încercări de sinteză apărute între anii 1962-1965 în revistele literare: „volumul dezvăluie un comentator cu preocupări diverse (...) care receptează cu seriozitate fenomenul literar contemporan, înclinat spre o critică cumpătată, înțelegătoare și clementă, ferindu-se în genere să facă judecăți ferme de valoare." Incercările de sinteză probează spiritul critic al autorului, dovedesc un gust literar bun și faptul că „știe să pătrundă în structura interioară a operelor, că știe să scoată în relief elementele rezistente, sub raport estetic, pe care operele le conțin."

D. Nica recenzează volumele nouă și zece din „Limbă și literatură” care au apărut cu prilejul comemorării a 75 de ani de la moartea lui Mihai Eminescu și Ion Creangă. Volumul nouă cuprinde studii semnate de nume reprezentative (G.C.Nicolescu, S.E.Demetrian, Mihail Pop, N.I.Popa) dedicate exclusive celor doi mari scriitori. Sunt amendate câteva "studii” care "nu-și justifică existența într-o astfel de publicație". Volumul zece cuprinde studii grupate în rubricile specifice ale revistei: teorie, critică și istorie literară, limbă și stil, folclor, metodica predării limbii și literaturii române, texte și documnete, bibliografie.

La finalul analizei sale, după o evaluare riguroasă a studiilor care alcătuiesc cele două numere ale revistei, D. Nica notează că „din toate punctele de vedere, volumul zece se situează deasupra volumului nouă."

\section{Bibliografie:}

Ateneu, ianuarie-iunie 1966.

Antofi Simona, Contemporary Critical Approaches to the Romanian Political and Cultural Ideology of the XIXth Century - Adrian Marino, Al treilea discurs. Cultura, ideologie si politica in Romania / The Third Discourse. Culture, Ideology and Politics in Romania, în Antofi, S., Ioana N., Necula, G., Ifrim, N., Crihană, A., (edit.), Procedia Social and Behavioral Sciences, 4th International Conference on Paradigms of the Ideological Discourse - The Dynamics of Terminologies and (Re)Shaping of Ideologies, 2012, p. 22-28, DOI: 10.1016/j.sbspro.2012.10.005, Galati, ROMANIA, 31 mai - 1 iunie 2012, Accession Number WOS:000361477200004 
Antofi, Simona, General Dictionary of Romanian Literature - Obverse and Reverse Critical Reception, în Oana Cenac (coord., edit.), International Conference of Common Vocabulary/Specialized Vocabulary: Manifestations of Creativity of Human Language, 6-7 iunie 2014, publicate în volumul MANIFESTARI ALE CREATIVITATII LIMBAJULUI UMAN, 2014, p. 13-19,ISBN:978-606-17-0623-5, WOS:000378446400001, https://apps.webofknowledge.com/full record.do?product $=W O$ SEsearch mode=GeneralSearchEqid=2ESID $=$ N1izysiav2ciPKZmp8PEpage $=1 \mathcal{E}$ doc $=3$. Ifrim, Nicoleta, Memory and identity-focused narratives in Virgil Tănase's 'lived book', CLCWeb: Comparative Literature and Culture (ISSN 1481-4374) http://docs.lib.purdue.edu/clcweb/, nr. 19.2 / June 2017, Purdue University Press, p. 1-10, accesibil la adresa http://docs.lib.purdue.edu/clcweb/vol19/iss2/4/, https://doi.org/10.7771/1481-4374.2942 WOS: 000404572300004.

Ifrim, Nicoleta, History and Identity in Post-Totalitarian Memoir Writing in Romanian, CLCWeb: Comparative Literature and Culture (ISSN 1481-4374) http://docs.lib.purdue.edu/clcweb/, nr. 16.1 / March 2014, Purdue University Press, revistă indexată ISI Art and Humanities Citation Index http://docs.lib.purdue.edu/clcweb/vol16/iss1/11/, Accession Number WOS: 000333326200011. 